\title{
Development of information system for evaluation of valley ecological carrying capacity
}

\author{
Jun YU1, a , Changshou LUO $2, \mathrm{~b}^{*}{ }^{3, c}$ Qingfeng WEI \\ ${ }^{1}$ Institute of Information on Science and Technology of Agriculture, Beijing Academy of Agriculture \\ and Forestry Sciences,Beijing,China \\ ${ }^{2}$ Beijing Research Center of Engineering Technology on Rural Distance Information Service, \\ Beijing,China \\ aYuj@agri.ac.cn, 'buocs@agri.ac.cn, 'Weiqf@agri.ac.cn
}

Keywords: Valley. Ecological carrying capacity. Oracle. C\#

Abstract. In order to dynamically obtain the ecological loading status in the valley unit, based on the spatial-temporal database and valley ecological carrying capacity model, the information system for evaluation of valley ecological carrying capacity was developed with GIS, Oracle and C\#. The software and hardware, system structure and technical characteristics, evaluation system module and system function have been designed in this paper.

\section{Introduction}

The valley ecological carrying capacity is an important index for valley environment evaluation. It is the precondition of mountain valley economy sustainable development and the basis of make plan. At present, most of the present study is a qualitative research. It is unable to guide the actual implementation and operation. How to quantify the valley ecological carrying capacity, and fast to evaluate the ecological status, has always been one of the difficult points of the valley ecological environment evaluation.Based on valley ecological carrying capacity model building, used the C\#, Oracle, and ArcGIS, the valley ecological capacity evaluation system is developmented to get the valley ecological loading status dynamically. It can provide effective decision-making basis for economic progress management.

\section{Evaluation Model}

Use ecosystem loading index, pressure index and the pressure bearing degree to describe the condition of valley ecosystems. This method is more systematic, comprehensive, integrated, and simple, easy to operate.

Ecosystem loading index. Ecological loading capacity include ecological flexibility index, resources carrying index and environment carrying index.

(1)Ecological flexibility index expression :

$$
\mathrm{CSI}^{\text {eco }}=\sum_{i=1}^{\mathrm{n}} \mathrm{S}_{i}^{\text {eco }} \times \mathrm{W}^{\text {eco }}
$$

$\mathrm{CSI}^{\mathrm{eco}}$ _Ecological flexibility index ; 1

S- Topography, soil, vegetation, climate and hydrology;

W_-Weight of Elements of ecological system.

(2)Resources carrying index expression:

$$
\mathrm{CSI}^{\text {res }}=\sum_{i=1}^{\mathrm{n}} \mathrm{S}_{\mathrm{i}}^{\text {res }} \times \mathrm{W}^{\text {res }}
$$

CSIres_-Resources carrying index ;

S_-Resource elements, $\mathrm{n}=1,2,3,4$, on behalf of land, water, tourism and mineral resources ; 
W-Weight of resource composition.

(3)Environment carrying index expression:

$$
\mathrm{CSI}^{\mathrm{env}}=\sum_{\mathrm{i}=1}^{\mathrm{n}} \mathrm{S}_{\mathrm{i}}^{\mathrm{env}} \times \mathrm{W}^{\mathrm{env}}
$$

CSIenv—— Environment carrying index

$\mathrm{S}$-Environment elements, $\mathrm{n}=1,2,3$, on behalf of land, water, tourism and mineral resources ;

W-Weight of environment composition.

Ecosystem pressure index expression. Ecosystem pressure index reflects the human ecosystem by population carrying capacity of a certain quality of life and corresponding quality of life.

$$
C P I^{\text {pop }}=\sum_{i=1}^{n} S_{i}^{\text {pop }} \times W^{\text {pop }}
$$

CPIpop_-Ecosystem pressure index.

$\mathrm{S}-$ Population of different groups;

$\mathrm{W}$ - The weight of the population of the corresponding group

Ecosystem bearing pressure index expression.

CCPS— Ecosystem bearing pressure index

$$
\mathrm{CCPS}=\frac{\mathrm{CCP}}{\mathrm{CCS}}
$$

$\mathrm{CCP} \longrightarrow$ Support capacity ;

CCS Pressure。

When it $>1$, carrying overload. When $<1$, carrying low load. When it $=1$, the load bearing pressure is balanced.

\section{System design and implementation}

System structure design. The system is developed based on client/servier. It builts the data safe system to allow the user operate data after registration licensing and logining. The data operate authority is applied by users to the administrator. After authority, user can set the fators of the modle and get the analysis result. The setting factors and analysis result are reserved in the temple table. At the same time, the thematic map is formed by GIS spacial analysis. After the review, reserve into the library as data analysis result and the thematic maps. By the analysis above, the system should include 5 modules: user admin module, data admin module, data analysis module, result output module and GIS analysis module. The structure figure is as follows:

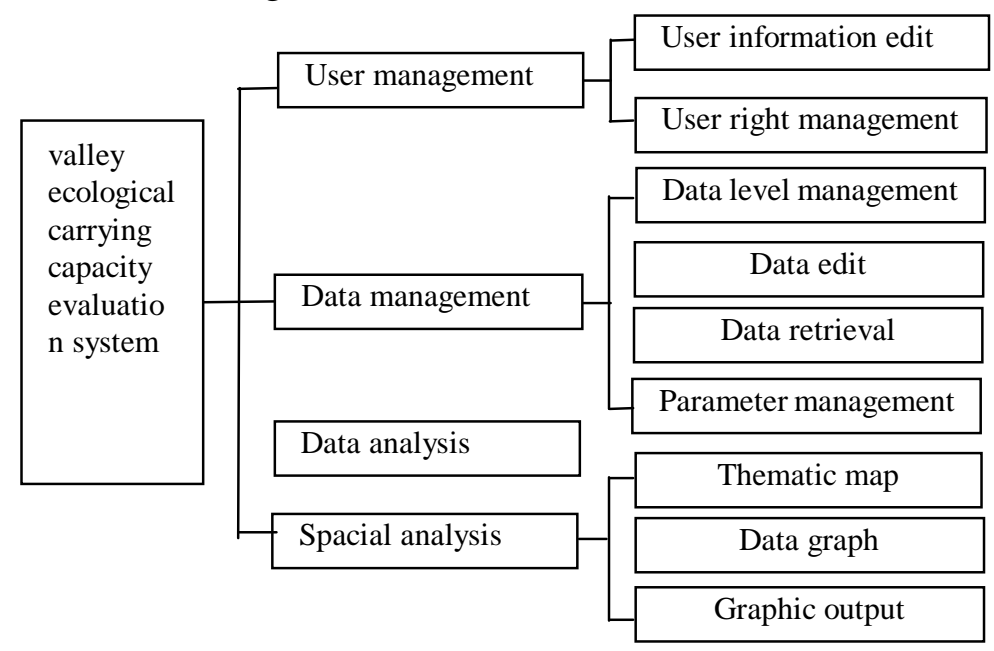

Fig 1. System structure 
System Development Environment Design. The system is developed by Net4.0, Oracle 11, ArcSDE10, and and ArcGis Engine 10 on Window 7. Oracle has advantages of the strong data autonomy, improve storage mechanism, easy operation, high efficiency information management. Its security and data confidentiality is higher than comparable products on the market.It is currently the most popular relational database. GIS is a tool of spacial analysis and graphical display. It can forecast analysis and make planning based on the combination of the map and its relational database. ArcSDE is a geographic information data server for spacial data management and operation based on serval relation database. It provides spatial data sharing across the network and between many users. ArcGis engine is a embedded development components for customized development GIS application in ArcGis platform.

Database design. Through the analysis of the target, and the characteristics of the data, the database of Oracle is chosen as basic data storage platform. It is mainly used for storage of spatial data and attribute data. By writing the Oracle triggers, to realize the constraints of tables and records, so as to ensure the integrity of the database. For the remote sensing data, due to its large amount, and low access frequency, therefore, it is saved in the form of files in the file system. It fully uses the combination of the database and file system to improve the performance of system efficiency.

\begin{tabular}{|c|c|c|}
\hline Table name & Content & Instructions \\
\hline gyjbxx & $\begin{array}{l}\text { Valleys basic information } \\
\text { table }\end{array}$ & Include valley ID, valley name ,etc.. \\
\hline natureinfo & $\begin{array}{l}\text { Valley natural resource } \\
\text { information table }\end{array}$ & Include altitude, precipitation ,etc.. \\
\hline shengtaihuanjing & $\begin{array}{l}\text { Valley ecological } \\
\text { information table }\end{array}$ & $\begin{array}{l}\text { Include Forest coverage, investment in } \\
\text { environmental protection, etc.. }\end{array}$ \\
\hline JINGJISHUJU & $\begin{array}{l}\text { Valley economy data } \\
\text { information table }\end{array}$ & $\begin{array}{l}\text { Include the main business income and other } \\
\text { information }\end{array}$ \\
\hline $\begin{array}{l}\text { lengkouqingkuang } \\
\text { huizhong }\end{array}$ & Valley population table & \\
\hline$\ldots \ldots$ & & \\
\hline
\end{tabular}

\section{System Function}

Evaluation model implementation. For the complexity of the relationship between data, frequency of data calculation and the computing power of database server, use the database transaction technology and Oracle SQL to implement model calculation. The main SQL code fragment is as follows:

(1) The ecological elasticity

Select valley ID, valley name, decode ( sign ( round ( ( the highest elevation - the lowest elevation ) / 2298,3 ) - 1 ) , -1 , $1 * 0.17$, round ( ( the highest elevation - the lowest elevation ) / 2298,3)*0.17) as terrain fluctuation coefficient, decode ( sign ( average annual precipitation - 700), - 1 , round ( average annual precipitation / 700 , 3 ) * 0.26, 0.26) as years of average rainfall from nature info where time='2009' and valley ID like 'D110111\%'.

(2) Resources carrying capacity

select a.valley ID , a.valley name, decode ( sign ( round ( a.water resources quantity / b.total population , 6 ) - 1000 ) , - 1, round ( a.water resources quantity / ( b.total population * 1000 ), 6 )* $0.36,0.36)$ as water resources quantity from SHENGTAIHUANJING a , LENGKOUQINGKUANGHUIZHONG $\mathrm{b}$ where a.valley ID = b.valley name and a time = ' 2009 ' and b.time = ' 2009 ' and a.valley ID like 'D110111\%' and b.valley code like ' D110111\%'. 
(3) Environmental carrying capacity

select valley ID, valley name, decode ( sign ( decode ( surface water quality grade , ' Class I ', 100 , 'Class II ', 80 , ' Class III' , 60 , ' Class IV ' , 40 , ' Class V ' , 20 , 'Weak V' , 0 ) - 100 ), - 1, decode ( surface water quality grade,'Class I ' , 100 , ' Class II ', 80 , ' Class III ' , 60 , ' Class IV ' , 40 , ' Class $\mathrm{V}^{\prime}, 20$, ' Class weak V' , 0 ) / $100 * 0.2,0.2$ ) as surface water quality grade, decode ( the success rate of air quality level 2 days - 100$),-1$, the success rate of air quality level 2 days / $100 * 0.18,0.18$ ) as the success rate of air quality level 2 days, decode ( sign ( the success rate of drinking water's quality - 100$),-1$, the success rate of drinking water's quality / $100 * 0.13,0.13$ ) as the success rate of drinking water's quality, decode ( sign ( rural sewage concentration rate - 100 ) , -1, centralized treatment rate of rural sewage $/ 100 * 0.09,0.09)$ as centralized treatment rate of rural sewage from code like ' D110111\% ' and a.Valley ID=b. Valley ID.

System function.

(1)Map display and browse. It includes the map layer visibility control, map to zoom, pan and move. It allows the user deeply observe their interest map.

(2)Query and statistic. By query and statistical module , users can get the data query and statistics result in the authorization.

(3) Data management module. The user can add, modified and delete the basic data.

(4)Computer module. Scientific analysis based on the specified underlying data and parameters to generate the results in table form output.

(5)Thematic map generation. Display the table value in a variety of space graphics.

(6) Statistics charts generation module. Display the table value in a variety of statistics charts

System running instance.Evaluation is analysis of the current data sample based on the set parameters and standard. Therefore, only when the parameters sample is determined, the current data can be analyzed. Sample parameter settings is shown in Figure 2.

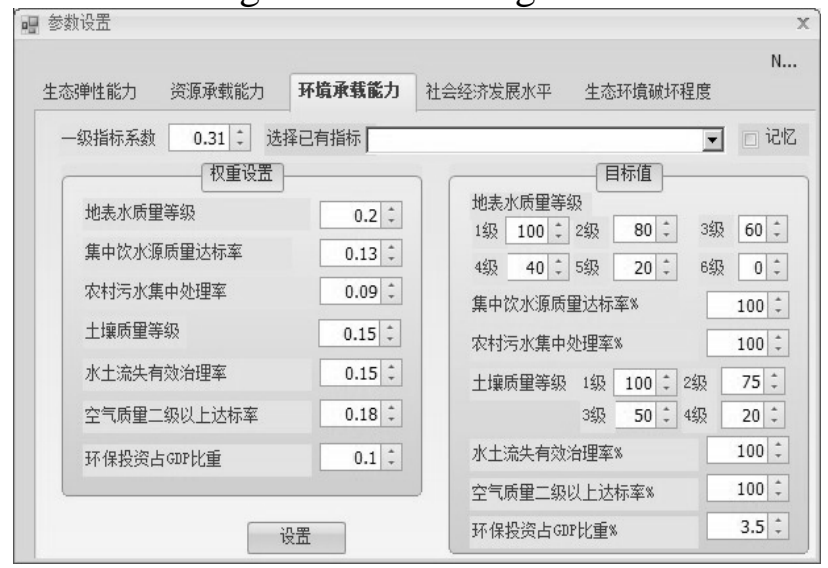

Fig2. Preferences window

After analyzing a valley, the results are shown in Figure 3.

\begin{tabular}{|c|c|c|}
\hline \multicolumn{3}{|c|}{ 吅 属性编辑器 } \\
\hline & 名称 & 内容 \\
\hline$>$ & 沟域代码 & D110111202 \\
\hline & 沟域名称 & 大石窝云居仙谷沟域 \\
\hline & 生态弹性能力 & 0.1976892960 \\
\hline & 资源承载能力 & 0.205066590150 \\
\hline & 环境承载能力 & 0.241180 \\
\hline & 社会经济发展水平 & 0.2804794614658560 \\
\hline & 水土流失面积比重 & 0.00000084 \\
\hline & 承载能力 & 0.643935886150 \\
\hline & 压力状况 & 0.2804803014658560 \\
\hline & 生态经济承载力评价 & 低负荷 (生态系统压力未超出生态承载能力) \\
\hline
\end{tabular}

Fig3 Valley analysis result 
After the multi-valley spatial analysis, spatial distribution is shown in Figure 4.

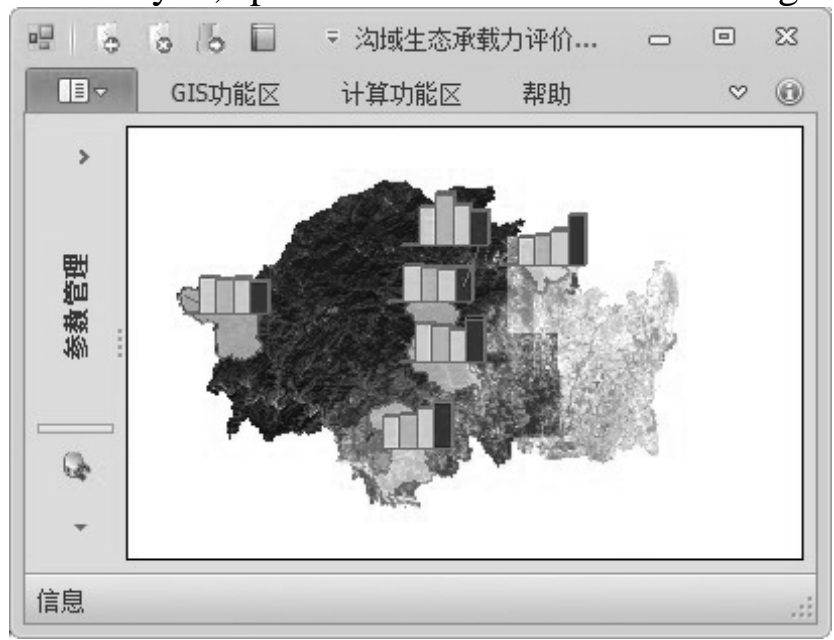

Fig4 Multi-channel analysis result display

\section{Conclusion}

Using C \# and Oracle, reduce programming difficulty and workload, shorten the development cycle. At the same time, to facilitate application development and code maintenance. The test results show that the system can effectively collect data for analysis, easy to use, intuitive and diverse forms of output.

\section{Acknowledgments}

The research work was supported by the National Sci-Tech Support Plan"Construction and application of provincial rural information service platform in developed area" ( NO.2014BAD10B02 ), the young scientist fund of BAAFS:Research on agricultural scientific technical online counseling system based on the knowledge map ( NO.QNJJ201534), The innovation fund of BAAFS: Devlopment and application of “zhinongtong”APP( NO.KJCX20140424 ). The corresponding author is Changshou Luo(luochangshou@163.com).

\section{References}

[1]Tang Guoan, Yangxi. ArcGIS geographic information system spatial analysis experiment course. Science Press, 2016,96-97.

[2]Huang Yapin, Xu Youqing.Construction of Soil Cultivation Suitability Assessment System based on GIS. Modern Surveying and Mapping, 2010,33(6):50-56.

[3]Chen Junhong, Zhou Liandi. Research on the development of Beijing Gully Region. China Economic Publishing House, 2013.114-156.

[4]Li wei , Wang Xiaochuan, Li Rongwu etc. Research on web-based ancient ceramics identification and analysis system. Computer Applications and Software. 2013,30(4):19 - 21 .

[5]Gao Jixi. Exploration on the theory of ecological carrying capacity— - the method and application of the theory of ecological carrying capacity. China Environmental Science Press, 2001. 
[6]Den bo, Hong Fuzeng, Gao Hongwen. A New Subject of the Studies on Sustainable Development of Grassland Region:Ecological Carrying Capacity. Journal of Jilin Agricultural University, 2003, 25 ( 5) : 507-512.

[7]Wang shuzhuan. Exploration and Analysis of Ecological Carrying Capacity Research Method. Environment and Ecology in the Three Gorges, 2009, 2 ( 5) : 1-4. 